\title{
Cold Spring Harbor Laboratory Cancer
} Center

National Cancer Institute

\section{Source}

National Cancer Institute. Cold Spring Harbor Laboratory Cancer Center. NCI Thesaurus. Code C39335.

The Cold Spring Harbor Laboratory Cancer Center is a basic research facility devoted to the understanding of the fundamental biology of human cancer. It is committed to exploring the molecular basis of human cancer through a focused, multidisciplinary approach to improve the diagnosis and treatment of all major forms of the disease. The center became an NCl-designated cancer center in 1987. 